\title{
THE EFFECTIVENESS OF KUPANG CITY OUTER RING ROAD DEVELOPMENT
}

\author{
Djaha Anwar*, Djani William, Nursalam \\ Master's Study Program of Administrative Sciences, Postgraduate Program, \\ University of Nusa Cendana Kupang, Nusa Tenggara Timur, Indonesia \\ *E-mail: anwar012201965@gmail.com
}

\begin{abstract}
This research aimed to describe and analyze (1) the effectiveness of the outer ring road development in Kupang City, Nusa Tenggara Timur, Indonesia and (2) the supporting and inhibiting factors of the outer ring road development. This research used a qualitative and case study approach. We determined the research location using a purposive technique (using certain considerations). We studied Kupang City Outer Ring Road, which is a National Road. The research focused on (1) the effectiveness of the outer ring road development, which are divided into two sub focuses (a) goal attainment approach and (b) system approach; (2) factors influencing the development of the outer ring road. We determined informants using the purposive technique. The data source was primary and secondary data. The data collection used interviews, documentation, and observation. We used Miles and Huberman's data analysis technique. We used the data triangulation technique to validate data. The research result showed (1) ineffective outer ring road development in Kupang City. We determined the effectiveness of the outer ring road development through the goal attainment and system approaches; (2) there were supporting and inhibiting factors. The supporting factors were: (a) the need and demand for an alternative road to reduce traffic jams in the city road; (b) the need and demand for equitable distribution of economic development in areas around the outer ring road; (c) the outer ring road is a strategic national road. State Revenue and Expenditure Budget (Anggaran Pendapatan dan Belanja Negara - APBN) funds the road development.
\end{abstract}

\section{KEY WORDS}

Effectiveness, development, road.

The Government of the Republic of Indonesia annually allocates APBN through the Ministry of Public Works and Housing to develop infrastructures such as roads, bridges, houses, irrigation facilities, sanitation, and reservoirs or dams. Based on Bina Marga ${ }^{1}$, the total length of the National Road in the Nusa Tenggara Timur Province is $1,857.91 \mathrm{~km}$. X Kupang National Road Implementation Center manages the National Road in Nusa Tenggara Timur Province under the Directorate General of Highways of the Ministry of Public Works and Housing of the Republic of Indonesia (Decree of the Minister of Ministry of Public Works and Housing number 248/KPTS/M/2015).

One of the segments is the Kupang City Outer Ring Road (segment length of 22.00 $\mathrm{Km}$ ). The Kupang City Outer Ring Road (section number 440050) is a road section registered as part of the national road in 2015. Kupang City Outer Ring Road was planned to be built in 1970. However, the development experienced many constraints, such as funds and land acquisitions.

The outer ring road may become the alternative road to support public and goods movement between Kupang City and other regions and support the regional economy.

Public policy on infrastructure development is part of a government program that supports public welfare. As the beneficiary of the program, the community needs to evaluate the government program. The evaluation may improve the effectiveness of development programs. There were obstacles in the outer ring road development of Kupang City. Therefore, the road segments could not follow the original plan. However, there were positive

\footnotetext{
${ }^{1}$ Implementer of the policy at the Ministry of Public Works and Public Housing.
} 
impacts of the outer ring road development. For example, the population growth along the road segments. Population growth promotes population distribution and deters the accumulation of population in the city area.

We noted the economic growth in the outer ring road. For example, stores, restaurants, and services. In addition, the National Road segment increases the selling price of community land near the outer ring road.

The positive impact has been part of the initial objective of the road and bridge development program in Kupang City Outer Ring National Road. We measured the positive impact by studying the effectiveness of public policy and budget allocation for infrastructure development. We also identified factors influencing the effectiveness of road and bridge development programs under the central government or local governments.

Therefore, we performed a study on "The Effectiveness of Outer Ring Road Development in Kupang City". The research aimed to analyze and describe (1) the effectiveness of outer ring road development in Kupang City and (2) the supporting and inhibiting factors influencing the effectiveness of outer ring road development.

\section{LITERATURE REVIEW}

The administration is the entire process of implementing decisions that have been taken and carried out by two or more people to achieve predetermined goals (Siagian, 2009:4). Liang Gie (in Pasalong, 2011:3) defines administration as a series of activities on the work carried out by a group of people to achieve certain goals.

According to Siagian (2009:4), development is a series of efforts to realize growth and change in a planned and conscious manner. Development essentially aims to improve and improve the quality of human life. Development needs to be implemented into various development programs that directly affect the community. Development requires ways or guidelines for action to improve the quality of human life. The policy is a set of guidelines that provide direction in implementing development strategies (Suharto, 2006:4).

Todaro (in Suharto, 2006:3) argues that development must have three interrelated objectives, namely:

- Increasing the availability and expanding the distribution of necessities such as food, housing, health, and protection to all community members;

- Achieve quality of life, improve material welfare, community self-confidence, and national independence. This aspect refers to increasing income, providing employment, education, culture, and human values;

- Expanding economic and social opportunities for individuals and nations through liberation from slavery, dependence on other people or nations, and liberation from ignorance and suffering.

Siagian (2009:5) defines development administration as all efforts made by a nation to grow, develop, and change in a conscious and planned manner in all aspects of life and livelihood. Mostopadidjaya (in Afifuddin, 2010:51) states that development administration refers to an administrative system capable of carrying out various functions of government and development effectively and efficiently.

Based on the theory of development administration, a nation needs to develop through government action. Development administration formulates development programs and policies to improve community welfare.

Afifuddin (2010:64) states that the focus development administration is the development process carried out by a nation to achieve the goals and ideals of a particular country or nation, including scientific methods used in solving problems, facing challenges, taking advantage of opportunities and eliminating threats. The characteristics of development administration distinguish it from other disciplines, namely:

- The development administration is oriented to efforts to change for the better;

- Development administration carries out administrative improvements related to development aspects in other fields such as economics, social, politics, and others. 
Government programs and policies generally aim to achieve certain objectives. However, the policy or program implementation encounters unexpected factors and fails to achieve the initial objectives. Therefore, it is necessary to evaluate government programs and policies. One of the basic aspects that determine the success of a program or policy is effectiveness. According to Atik and Ratminto (2005:174), effectiveness is the achievement of a predetermined goal, both in the form of targets, long-term goals, and organizational missions. According to Siagian (2001:24), effectiveness is utilizing resources, facilities, and infrastructure in a certain predetermined amount to produce goods or services. Effectiveness shows the extent of objective achievement. Higher achievement indicates higher effectiveness. Effectiveness determines the success of a program and policy through predetermined objectives. High effectiveness illustrates the program and policy's ability to achieve predetermined objectives and goals.

Henry, Brian, and White (in Wibawa, 1994:65), suggest several aspects that can be used to determine the effectiveness of a program or policy, namely: (1) Time of achievement (2) Level of the desired effect. (3) Changes in community behavior. (4) Lessons learned by project implementers. (5) The level of public awareness of their abilities. The level of effectiveness can be assessed from the achieved result. Effectiveness refers to achieving a predetermined target. Ineffectiveness refers to failure to achieve a predetermined target. Therefore, it is necessary to construct indicators to measure effectiveness.

Robbins (1990:53-57), borrowing the opinion of Kim, revealed four approaches to measuring organizational effectiveness:

Goal Attainment Approach. This approach measures how predetermined objectives are achieved. In this approach, the emphasis is on the result and not the method. The goals need to be clear, have a time limit, and be measured. Siagian (2001) states the criteria or measures on objective achievement:

1. Clarity of goals. Employees can achieve targeted goals and organizational goals;

2. Clarity of strategy. The strategy allows the implementer to achieve organizational goals;

3. Analysis process and policy formulation. The policy must be able to bridge the objectives and operational activities;

4. Careful planning essentially means deciding what the organization will do in the future;

5. Preparation of the right program. A good plan needs to be translated into appropriate implementation;

6. Availability of work facilities and infrastructure. One indicator of organizational effectiveness is the ability to work productively. Available facilities and infrastructure improve effectiveness;

7. Effective and efficient implementation. The organization will fail to achieve goals without effective and efficient implementation;

8. An educational system of supervision and control. The effectiveness of the organization requires a system of supervision and control.

System Approach. Measures the availability of needed resources, maintains itself internally as an organism, and interacts successfully with the external environment. It is necessary to have a clear relationship between input and output. The term system is now widely used. The concepts related to the system have been applied in various system designs, such as problem solving and management. A system consists of any collection, parts, and components (physical and non-physical) interconnected and working together in harmony to achieve a certain goal. The basic model is input, processing, and output.

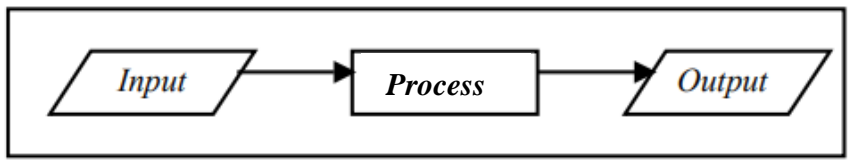

Figure 1 - Basic Concept of a System (Susanto, 2004) 
According to Hardcastle (2011: 8) system aims to receive and process input. Systems produce output in the form of information. There are five general components of the system: input, process, output, feedback, and control.

The general model of a system consists of inputs, processes, and outputs. This is a very simple concept considering that a system can have multiple inputs and outputs at once. A system has characteristics or properties, such as (1) System Components (Components). A system consists of components that interact with each other, which means they work together to form a single unit. Components can be a form of subsystem. Each subsystem has the properties of the system to run a particular system and affects the overall system process. (2) Boundary System (Boundary) is an area that limits the system with other systems with the outside environment. The system boundary indicates the scope of the system. (3) External Environment (Environment) (Sutabri, 2012).

Organizational effectiveness must be able to describe the entire cycle of input, process, and process outputs. Organizational effectiveness must describe the harmonious relationship between the organization and the wider environment. Based on the time dimension, the organization is defined as an element of a larger system (environment) such as collecting resources, processing resources, and producing goods. The organization will distribute the goods to the environment (Hasanbasri, 2007).

A system consists of inputs, processes, and outputs. Input consists of raw materials. The process is a strategy to process raw materials into products. Output is the product of goods purchased or consumed by users. Outcomes are benefits felt by users or parties outside the system (Hasanbasri, 2007).

\section{METHODS OF RESEARCH}

This research used a qualitative approach and case study method. The researchers determined the research location using the purposive technique (using certain considerations). The researchers studied the Kupang City Outer Ring Road segment. The Kupang City Outer Ring Road is part of the National Road under The Ministry of Public Works and Housing. The research focused on (1) the effectiveness of outer ring road development and (2) factors influencing effectiveness. The first research focus was divided into the following sub-focus: (a) goal attainment approach, meaning that this research compared the objective and real condition of Kupang City Outer Ring Road development, and (b) System approach, meaning that this research measured input, process, output, and outcome effectiveness This research determined inhibiting and supporting factors influencing road development. The researcher determined informants using the purposive technique (using certain considerations). The data source was primary data and secondary data. Data collection used interviews, observation, and documentation. We analyzed data using Miles and Huberman (2007), which divided data analysis into data reduction, data presentation, and conclusion/verification. We used data triangulation to validate the research result.

\section{RESULTS AND DISCUSSION}

The researcher studied the Kupang City Outer Ring Road development based on the goal attainment approach and system approach. The research result showed the ineffectiveness of outer ring road development.

The goal attainment approach determined the alignment between the objective and real condition of Kupang City Outer Ring Road development. The outer ring road development objectives were to reduce traffic (especially large vehicles and expedition vehicles) inside the city, increase traffic in the outer ring road, and increase the economic activity in the outer ring road. However, the government did not achieve any of the development objectives. Therefore, the outer ring road development was ineffective.

The researcher determined the research result based on the system approach (input, process, output, and outcome). The researchers found several obstacles that influence the development process. The input stage showed a lack of planning. The plan had several 
changes as the outer ring road development passed the densely populated residential area. The process stage showed several obstacles due to land acquisition and budget constraints. The output stage showed several obstacles due to constraints in the input and process stage. Therefore, the outer ring road development was ineffective.

Based on the goal attainment approach and system approach, the supporting factor influencing outer ring road development are: (1) the need and demand for an alternative road to reduce traffic in the city road; (2) the need and demand for equitable distribution of economic development in suburban areas around the outer ring road; (3) APBN funds the outer ring road development as Kupang City Outer Ring Road is part of National Road.

The inhibiting factor influencing the outer ring road development are: (1) lack of planning causes several changes during implementation; (2) constraints during development; (3) no compromise on land acquisition (between government and landowners); (4) budget constraints of the provincial government; (5) provincial government unable of performing political lobbying; (6) the Covid-19 pandemic; (7) lack of policy that requires heavy vehicles to use outer ring road; (8) the community's lack of understanding on the opportunity of outer ring road development; (9) the outer ring road has low traffic; and (10) land acquisition on a densely populated residential area.

The framework of the research result is presented in the following figure:

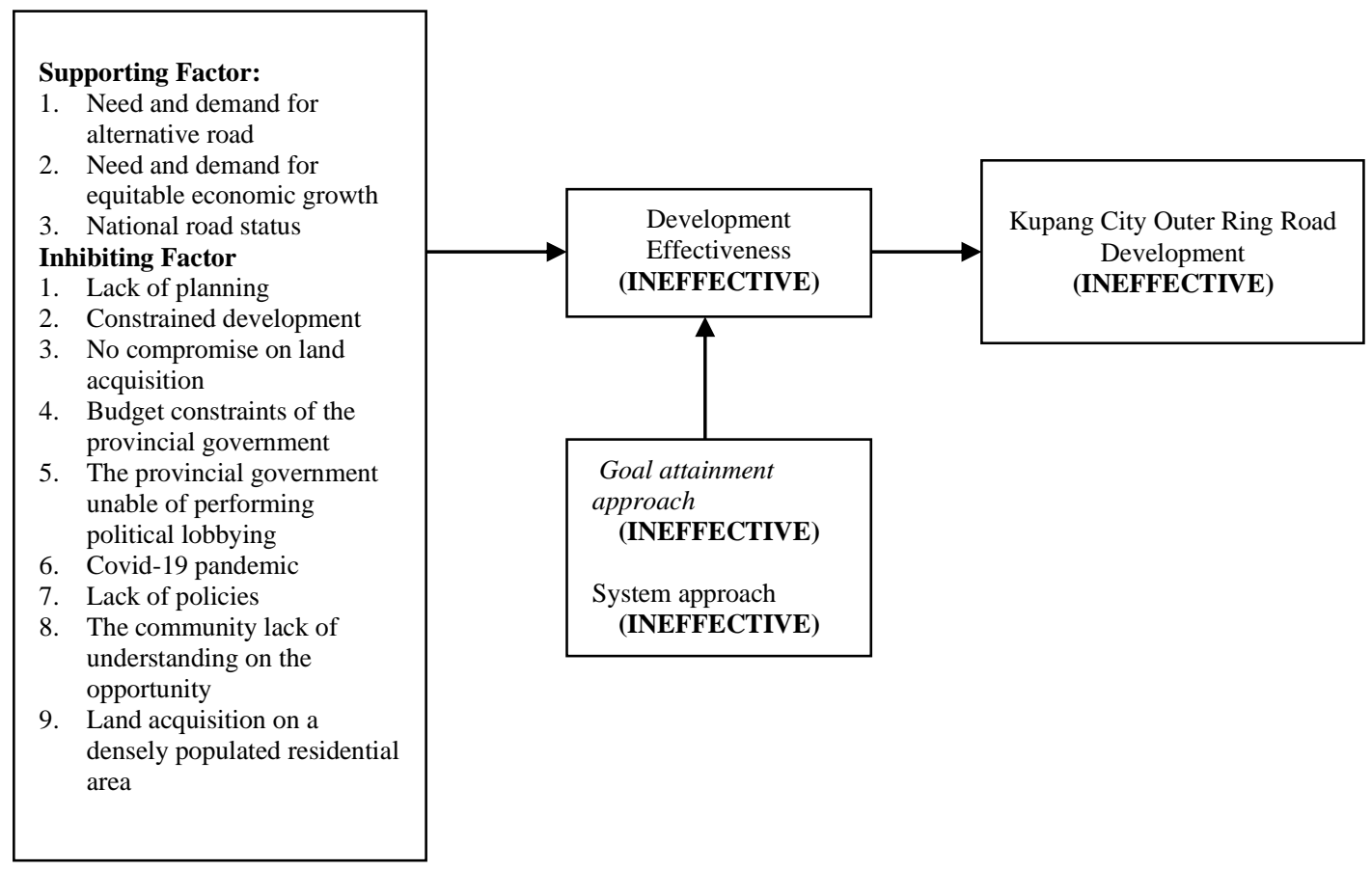

Figure 2 - The framework of Research Result

Based on the framework of research results, management issues caused the constraints of outer ring road development. Management is a strategy to implement leadership in an organization. Management covers several dimensions such as planning, organizing, directing, supervising, and utilizing organizational resources to achieve predetermined objectives. Kupang City Outer Ring Road development covers planning, organizing, directing, supervising, and utilization. Based on the research result, the managerial function focused on planning, organizing, directing, and supervising.

G.R Terry (1978 in Syahrizal, 2008:14) stated that management covers planning, activity implementation, and objective achievement through utilizing existing human resources. Management is the ability or power to manage a business and is responsible for the success and failure of the business.

The management dimension refers to managerial function. Terry (1978 in Syahrizal, 2008) refer management dimension as POAC (Planning, Organizing, Actuating, Controlling) 
Planning is an activity that determines the goal and the use of facilities. The allocation of very limited resources is the basic principle in planning and organizing. Planning determines the goal, method, and human resources. Planning considers technical, economic, social, and service aspects. Planning aligns the current status and the goals. Planning determines the number of activities that members of the organization must carry out. A clear plan allows every organization member to carry out activities, producing a maximum and positive contribution to the organization (Terry, 1978 in Syahrizal, 2008).

Research results showed ineffective planning management of outer ring road development. Ineffective planning refers to the changes in the development plan. Furthermore, the existing plan covers other problems and constraints of the outer ring road development. Therefore, the government failed to implement the initial development plan. The success of a program relies on good planning. Ineffective planning caused constraints on outer ring road development.

Organizing refers to managing existing resources (material and human resources). Organizing resources refer to the appropriate concept through respective functions such as task requirements, work procedures, the person in charge, and relations between functions. The functions form a relationship within a system. One function supports the other. Therefore, organizing refer to forming a relationship between all work activity, workforce utilization, and resources utilization through formal structure and authority (Terry, 1978 in Syahrizal, 2008).

Based on the research result, the management stage of outer ring road development was ineffective. The central government and local government failed to organize the road development. The central government is the first party and implementer of the road development program as the Kupang City outer ring road is part of the National Road. Therefore, Central Government funds road development through APBN. However, the local government was in charge of land acquisition. The local government's inability to work caused constraints on land acquisition. Therefore, the local government asked the central government to fund the land acquisition. Ineffective organizing caused ineffective outer ring road development.

Actuating refers to implementing and controlling organizational resources to achieve a predetermined goal. Actuating unite all activities to effectively and efficiently achieve predetermined objectives (Terry, 1978 in Syahrizal, 2008).

Actuating, in general, refer to a predetermined plan and organized resources. Based on the research result, the outer ring road development was ineffective. The actuating phase experienced constraints on land acquisition. The government changed the initial plan by rerouting the outer ring road. After rerouting the outer ring road, the government kept encountering constraints on land acquisition. Therefore, the government failed to finish the outer ring road development. The local government asked the central government to fund the land acquisition. However, the central government had no budget for land acquisition. Therefore, the central and local governments could not finish the road development program. An ineffective actuating process caused ineffective outer ring road development.

Controlling ensure good cooperation between organization member and achieve organizational goal. Controlling measures the work result and deter deviation. It is necessary to conduct corrective action on existing deviation.

The research result showed ineffective planning, organizing, and actuating processes due to ineffective management. Controlling reduces deviation. Therefore, controlling needs to be conducted throughout the managerial activity (planning, organizing, actuating, and controlling processes). The weak control caused a deviation in outer ring road management. Ineffective controlling caused ineffective outer ring road development.

\section{CONCLUSION}

The Kupang City Outer Ring Road development was ineffective based on the goal attainment and system approach. The goal attainment approach showed that the government failed to achieve the objectives of outer ring road development. System 
approach (input, process, output, and outcome) found several constraints which caused ineffective outer ring road development.

There are supporting and inhibiting factors influencing Kupang City Outer Ring Road development. The supporting factors are: (1) the need and demand for an alternative road to reduce traffic in the city road; (2) the need and demand for equitable distribution of economic development in suburban areas around the outer ring road; (3) APBN funds the outer ring road development. The inhibiting factor influencing the outer ring road development are: (1) Lack of planning causes several changes during implementation; (2) Constraints during development; (3) No compromise on land acquisition (between government and landowners); (4) budget constraints of the provincial government; (5) provincial government could not perform political lobbying; (6) Covid-19 pandemic; (7) lack of policy that require heavy vehicles to use outer ring road; (8) the community did not grasp the opportunity of outer ring road development. The outer ring road has low traffic; (9) land acquisition on a densely populated residential area.

Based on the research result, discussion, and conclusion, the researchers formulated the following suggestions:

1. Evaluate the development plan to deter changes in the future;

2. The provincial government needs to speed up the negotiation process with landowners. The provincial government needs to make a price comparison between landowner demand and community demand;

3. The provincial government needs to approach central-level political actors in the development sector to obtain funds from the central government (especially for land acquisition);

4. Conduct continuous socialization to the community surrounding the outer ring road, especially on the benefit of outer ring road development.

\section{REFERENCES}

1. Afifuddin. (2010). Pengantar Administrasi Pembangunan. Bandung: CV Alfabeta.

2. Atik dan Ratminto. 2005. Manajemen Pelayanan, Disertai Dengan Pengembangan Model Konseptual, Penerapan Citizen's Charter Dan Standar Pelayanan Minimal. Yogyakarta. Pustaka.

3. Hardcastle, D. A; Powers, P. R., dan Wenocur, S. 2011. Community Practice: Theories and Skills for Social Workers, 3rd Edition. New York. Oxford University Press.

4. Hasanbasri, 2007. Manajemen Puskesmas Dan Partisipasi Masyarakat Dalam MKegiatan Posyandu. http://lrc-kmpk.ugm.ac.id.

5. Miles, Mattew B dan Amichael Huberman. 2007. Analisis Data Kualitatif Buku Sumber tentang Metode-Metode Baru. Terjemahan Tjetjep Rohendi Rohisi. Jakarta. Universitas Indonesia.

6. Pasolong, Harbani. 2011. Teori Administrasi Publik. Alfabeta. Bandung.

7. Robins, Stephen. 1990. Perilaku Organnisasi. Jakarta. Prehalindo.

8. Robbins, Stephen P. 1994. Teori Organisasi: Struktur, Desain dan Aplikasi, Alih Bahasa Jusuf Udaya. Jakarta. Arcan.

9. Siagian, Sondang P. 2001. Manajemen Sumber Daya Manusia. Jakarta. Bumi Aksara.

10. Siagian, Sondang P. 2009. Manajemen Sumber Daya Manusia, Edisi.1, Cetakan.17. Jakarta. Bumi Aksara.

11. Suharto, Edi. 2006. Membangun Masyarakat Memberdayakan Rakyat. Bandung. PT Refika Aditama.

12. Susanto, Azhar. 2004. Sistem Informasi Manajemen. Bandung. Linggar Jaya.

13. Sutabri, Tata. 2012. Analisis Sistem Informasi. Yogyakarta. Andi.

14. Syahrizal, Abbas. 2008. Manajemen Perguruan Tinggi: Beberapa Catatan. Jakarta. Kencana.

15. Wibawa, Samodra; dkk. 1994. Evaluasi Keijakan Publik. Jakarta. PT Raja Grafindo Persada. 